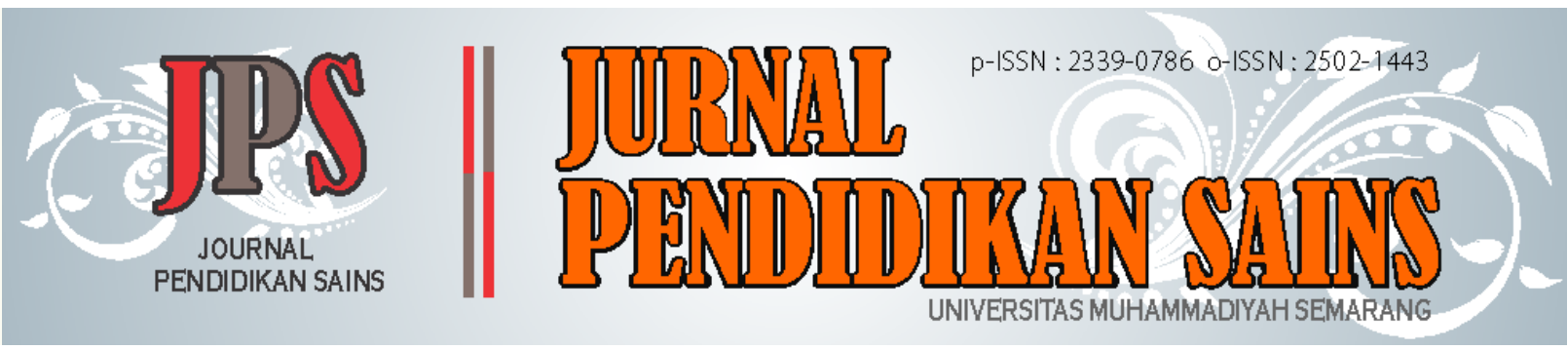

\title{
Meta-analysis of Using Handouts to Enhance Chemistry Student's Learning Outcomes
}

\author{
Pretty Lia Qoriah ${ }^{\mathrm{a}, 1, *}$, Rinaningsih ${ }^{\mathrm{b}, 2}$ \\ ${ }^{a}$ Department Of Chemistry, The State University Of Surabaya, Surabaya 60231, Indonesia \\ ${ }^{\mathrm{b}}$ Department Of Chemistry, The State University Of Surabaya, Surabaya 60231, Indonesia \\ ${ }^{1}$ pretty.17030194016@mhs.unesa.ac.id ; ${ }^{2}$ Rinaningsih@unesa.ac.id* \\ * corresponding author : Rinaningsih@unesa.ac.id
}

\begin{tabular}{lrr}
\hline \multicolumn{3}{l}{ Article history } \\
\hline Submission & $:$ & $2021-01-19$ \\
Revised & $:$ & $2021-02-16$ \\
Accepted & $:$ & $2021-03-05$
\end{tabular}

Keyword

Handouts

Chemistry

Learning Outcomes

\begin{abstract}
This article was written to report the well-prepared steps and their results of how the above mentioned concept was released. The method used is a metaanalysis method by comparing several similar articles to know the scientific effect of using them. The data collection technique used non-test, by browsing articles with Research Gate, Science Direct and DOAJ. Based on the result of the analysis, it was found that handouts can improve student learning outcomes. Comparison of student learning outcomes was observed from the percentage before and after using the handouts. Data analyzed used statistical test type paired sample. Based on the results of the analysis test from six studies on handouts, it was found that a significant increase in learning outcomes was $37,50 \%$. These results indicate that the use of handouts can be used to support chemistry learning.
\end{abstract}

\section{() $(1)$ \\ This work is licensed under \\ a Creative Commons Attribution 4.0 International License C2021 Jurnal Pendidikan Sains Universitas Muhammadiyah Semarang}

\section{INTRODUCTION}

Chemistry is a science subject that has high complexity and it's subject matter consist of three levels of representation, namely macroscopic, symbolic and sub microscopic dimensions. Therefore it is important that students master these concepts and the levels of representation because those concept are related to each other (Langitasari, 2016). Achievement of competencies in the learning process is highly dependent on the teaching materials used. They are all forms of material, both written or physical which are prepared by the teacher to support classroom learning. In compiling teaching materials, it is necessary to make student's characteristics a reference for designing learning (Budiningsih, 2015).

The teacher as a facilitator must adapt the substance, character, and insight that students have with teaching materials they used. Learning media consists of three forms, namely print-based media, electronic media and digital media (Wahidin, 2018). In this case, the teacher must design and determine the proper materials, so that they can encourage students to understand the concept or materials being studied more ease (Astari, 2018). One of the appropriate media to use when learning is handouts. Handouts are print-based media that contain summaries or parts of learning that are considered important so that students gain learning experiences through the sense of sight. At the end of each review, questions are asked to find out whether student's understanding the material, and also to determine their readiness to implement the handouts-scientific concept 
(Korniawati, Kusumo \& Susiloningsih, 2016). Handouts are also used as teaching materials for teachers in preparing lesson (Siti, Audina, Kokasih \& Respatih, 2018; Rahmayani, Hindun \& Hudha, 2015; Aini \& Masykur, 2018; Bhabiet, Accraf, Khery, Kimia, Mataram \& No, 2018; Salfrika, 2016).

Developing effective and attractive handouts is very important. There are many ways to develop them by paying attention to aspects such as content, structure, writing procedures and language styles. In addition, handouts must contain illustrations or images that can direct student's activities to become more active (Noorhidawati \& Gibb, 2008; Alsadoon, 2020; Fatma, Holiwarni \& Susilawati, 2016; Dwikristanto \& Listiani, 2018; An, Rochintaniawati, \& Fitriani, 2015). These aspects are also used as indicators to determine handouts are appropriate as a learning resource. Handouts can be suitable if they get a positive response after being tested on a limited basis in the classroom from both teachers and students (Habibati, Nazar \& Septiani, 2019; Haritsah Ulya, Ratu Betta Rudibyani, 2019; Sistyarini \& Nurtjahyani, 2017; Parsudi, Lukman \& Kartika, 2017; Sumiati, Arcana \& Taufiq, 2019).

Handouts play a role in improving language skills (Rokhimah, Fatmaryanti \& Nurhidayati, 2018; Irfandi, Linda \& Erviyenni, 2018 ; Pratama \& Sakti, 2020; Haristah, Azka, Setyawati \& Albab, 2019; Eliza, 2020; A. Agung, Ekayana, Tinggi \& Komputer, 2020). In this case the handouts are used as a learning resource to prepare materials for the class discussion process. The availability of material or discussion will facilitate student's language skills and self-efficacy involved in the discussion process (Zuhri, 2014). The use of handouts is to be able to solve problems and understand the close relationship with real-life learning to solve problems. This will direct students to develop their thinking skills and high-level cognitive processes such as critical thinking skills, scientific literacy and science processing skills (Saraswaty, Masykuri \& Mulyani, 2019; Rofiah, Aminah \& Sunarno, 2018; Suparmi, 2019; Purwo, 2016; Zohrani, 2018; Ahmadi \& Khery, 2013). Handouts have benefit as a learning alternative to improve the comprehensive intelligence of students, which includes knowledge, skills and attitude (Wati, 2017; Septryanesti, 2019; Nugroho, Ahmad \& Rohman, 2019; Arimadona \& Silvina, 2019; Novitasari, Masykuri \& Aminah, 2016; Abdurrahman, 2020; Liniswanti, 2015). In addition, handouts are used to optimize the concepts of students in the learning process (Wisnu, Wijaya, Fajar, Tukad, Ix \& Selatan, 2020; Plangsorn, 2017; Erba, 2020; Astuti, Saputro \& Mulyani, 2016; Situmorang, 2013; Wang, 2018; Herwati, 2016; Muriati, 2014; Dumitrescu, Olteanu, Gorghiu, \& Gorghiu, 2015; Anggela \& Darvina, 2013). Optimal learning can be observed from student's significant learning achievement (Meerah, 2019; Nursafitri, Widaryanto \& Zubaidi, 2020; Darma, Putra, Maulina \& Pohan, 2018; Nazar, 2018; Prastyaningrum \& Imansari, 2016; Silfi, Syakbaniah \& Kamus, 2014).

A review of several articles, compiled as a review article by comparing the percentage of handouts use on student's learning outcomes. Based on the explanation above, the research question in this article "What is the effect of using handouts to support chemistry learning on improving student learning outcomes?"

\section{METHOD}

The method used is Meta-analysis which is a method carried out by collecting, reviewing and analyzing the research data (Anugraheni, 2018). The data collected in this review article was carried out online using Research Gate, Science Direct, and DOAJ search engine to search for relevant research articles. The search for relevant research articles was carried out using handouts, learning outcomes, and chemistry keywords.

From the data search, articles that met the criteria for comparing learning outcomes before and after reading them were chosen. Then the differences in learning outcomes were analyzed using paired sample statistical test and the resulting percentage was decided.

The result of handouts data tracing consisted in six articles which discuss the percentage in differences between before and after reading the handouts. Six articles were used as comparison, and the way to do it was using pretest and posttest percentages (Muliawati \& Saputro, 2016; Sari, Kembaren \& Sudrajat, 2018; Mawarni, 2015; Pujiastuti, 2018; Agustina, S \& Mulyani, 2013; M. Agung, Cahyanto, Utomo \& Yamtinah, 2016). 


\section{RESULT AND DISCUSSION}

Handouts are teaching materials prepared by the teacher and can be used by students to develop their knowledge and insights. The discussion of handouts in this article was made to know the effect of using them to support chemistry learning outcomes. Handouts, as a learning resource presents a summarized material discuss in details.

The result analysis results were presented descriptively qualitatively and quantitatively. The percentage of results before and after the use of handouts can be observed in Table 1.

Table 1. Student Learning Outcomes

\begin{tabular}{llll}
\hline No & $\begin{array}{l}\text { Percentage } \\
\text { Increase (\%) }\end{array}$ & Of Learning & Outcomes \\
\cline { 2 - 4 } & $\begin{array}{l}\text { Before Use } \\
\text { Handouts }\end{array}$ & After Use & Enhancement \\
\cline { 2 - 4 } 1 & 29,11 & 86,42 & 57,31 \\
2 & 70,81 & 97,00 & 26,19 \\
3 & 58,00 & 83,00 & 25,00 \\
4 & 31,71 & 85,71 & 54,00 \\
5 & 27,78 & 77,78 & 50,00 \\
6 & 65,63 & 78,13 & 12,50 \\
Average & 47,17 & 84,67 & 37,50 \\
\hline
\end{tabular}

Based on the analysis results, it is known that in table 1, student learning outcomes have increased in those. The average percentage before using the handouts was $47,17 \%$ and after using was $84.67 \%$. The obtained results indicate an increase in learning outcomes by $37,50 \%$. Using handouts, students were asked to test their understanding by doing posttest questions. Student's learning outcomes have increased because students read the material and finally understand the material being studied.

After using handouts, the improved learning outcomes percentage was analyzed using the paired sample statistical test and this can be observed in Table 2, 3, and 4.

Table 2. Paired Samples Statistics

\begin{tabular}{|c|c|c|c|c|c|}
\hline & & Mean & $\mathrm{N}$ & $\begin{array}{c}\text { Std } \\
\text { Deviation }\end{array}$ & $\begin{array}{c}\text { Std } \\
\text { Error } \\
\text { Mean }\end{array}$ \\
\hline Pair & Before Use & 47.17 & \multirow{2}{*}{6} & \multirow{2}{*}{19.78918} & \multirow{2}{*}{8.07890} \\
\hline 1 & Handouts & 33 & & & \\
\hline & After Use & 84.67 & \multirow{2}{*}{6} & \multirow{2}{*}{7.05982} & \multirow{2}{*}{2.88216} \\
\hline & Handouts & 33 & & & \\
\hline \multicolumn{6}{|c|}{ Table 3. Paired Samples Correlations } \\
\hline & & & \multicolumn{3}{|c|}{ Correlatio } \\
\hline & & & $\mathrm{n}$ & Sig \\
\hline $\begin{array}{ll}\text { Pai } & \text { B } \\
1 & \&\end{array}$ & $\begin{array}{l}\text { efore Use Han } \\
\text { After Use Ha }\end{array}$ & & 5 & 0.342 & 0.508 \\
\hline
\end{tabular}

Table 2 shows the result of using handouts in chemistry learning from six articles. The average percentages before using the handouts is 47,17 and it increased 84,67. Whereas in Table 3 , it showed the correlation value before and after using the handouts, it reached a correlation 0,34 . Significant value was obtained, in $0,508>\alpha(0,05)$ indicating that there was no correlation between before and after using the handouts.

Table 4. Paired Samples Test 


\begin{tabular}{lccc}
\hline Pair 1 & $\mathrm{t}$ & $\mathrm{df}$ & $\begin{array}{c}\text { Sig. (2- } \\
\text { tailed) }\end{array}$ \\
$\begin{array}{l}\text { Before Use } \\
\text { handouts- }\end{array}$ & -4.938 & 5 & 0.004 \\
$\begin{array}{l}\text { After Use } \\
\text { handouts }\end{array}$ & & & \\
\hline
\end{tabular}

Table 4 shows the $\mathrm{t}$ value is $-4,938$, which is then used as hypothesis test. Hypothesis test can be concluded if $\mathrm{H}_{0}$ : there are no significant differences before and after using handouts to improve student's learning outcomes. $\mathrm{H}_{1}$ : There are significant differences before and after using handouts to improve student's learning outcomes.

After that the value of $\mathrm{T}$ table with $\mathrm{t} 0,975$ and $\mathrm{dk} 5$, the Obtained t count result was counted and dicided $(-4,938)<\mathrm{T}$ table $(2,75)$. So $\mathrm{H}_{0}$ is rejected, and $\mathrm{H}_{1}$ is accepted. This means that which states that there are significant differences in learning outcomes obtained by students before and after using handouts as supporting chemistry learning. Based on the results of statistical data processing, it can be seen that the use of handouts as a support for learning chemistry can help improve student learning outcomes.

The increase in learning outcomes is influenced by the contribution of the teacher in regulating the learning and reading processes (individual learning). Handouts implementation is an individual learning approach introduced by piaget, who states that learning must be built through the cognitive structure of students. The teacher will lead students, while they are focusing on the learning material and also read the related handouts, as by so doing they will increase their understanding of the concept. This activity will also improve their way of doing the teacher's assignments (Rinaningsih, 2014). In addition, there are handouts to find out the initial abilities, interest and motivation of student during the teaching learning process in the class. This is in accordance with the research of Haji, Safriana \& Safitri, 2015, with reveals that handouts can energize strength and good understanding. Good concepts earned by students can solve problems according to their abilities after reading the handouts.

Using Handouts in this article is to know whether it could enhance learning outcomes in tests given by the teacher at the end of a certain learning material. Teacher's tests can increase their cognitive process, so that their learning outcomes can also be enhanced. This premise is explained Irawati, 2014, which also adds that students with high cognitive process will be able to finish problems under standard concept, and solve problems more easily. According to Iza, 2018, explained that presenting learning material using handouts will enable students to construct a certain concept from one unit to another. So that this activity will give them more challenging and systematic experience.

\section{CONCLUSION}

Based on the articles discussed in this study, it can be concluded that the use of handouts to support chemistry learning can be taken into consideration, as this activity can become learning resources to be used as teaching materials. The learning outcomes showed a significant increase of $37,50 \%$. These results indicate that use of handouts can be used to support chemistry learning of students.

\section{REFERENCES}

Abdurrahman, S. (2020). Pengembangan Cergam Fisika Berbasis Stem untuk Menumbuhkan Literasi Sains pada Siswa SMP. 8, 11-23.

Agung, A., Ekayana, G., Tinggi, S., \& Komputer, I. (2020). Pengembangan Modul Pembelajaran Mata Kuliah Internet Of Things. 16(2), 159-169.

Agung, M., Cahyanto, S., Utomo, S. B., \& Yamtinah, S. (2016). Penggunaan Model Pembelajaran Cooperative Problem Solving (CPS) Dilengkapi Handout untuk Meningkatkan Kemampuan Berpikir Kritis dan Prestasi Belajar Siswa Materi Termokimia Kelas XI IPA Semester Ganjil 
SMA Negeri 3 Boyolali Tahun Pelajaran 2015/2016. 5(4), 43-50.

Agustina, E., S, A. N. C., \& Mulyani, S. (2013). Penggunaan Metode Pembelajaran Jigsaw Berbantuan Handout untuk Meningkatkan Aktivitas dan Prestasi Belajar Siswa pada Materi Pokok Hidrokarbon Kelas XC SMA Negeri 1 Gubug Tahun Ajaran 2012/2013. Jurnal Pendidikan Kimia (JPK), Universitas Sebelas Maret, 2(4), 66-71.

Ahmadi, H. P., \& Khery, Y. (2013). Pengembangan Modul Contextual Teaching And Learning (CTL) Berorientasi Green Chemistry Untuk Pertumbuhan Literasi Sains Siswa. 4(1), 17-25.

Aini, E. P., \& Masykur, R. (2018). Handout Matematika berbantuan Etnomatematika Berbasis Budaya Lokal. 1(1), 73-79.

Alsadoon, H. (2020). Obstacles to Using E-Books in Higher Education. International Journal of Education and Literacy Studies, 8(2), 44.

An, N. R., Rochintaniawati, D., \& Fitriani, A. (2015). Analisis Buku Biologi Kelas X Berdasarkan Muatan Literasi Sains Analisys of Biology Textbook for 10. Prosiding Seminar Nasional Pendidikan Biologi, 309-316.

Anggela, M., \& Darvina, Y. (2013). Pengembangan Buku Ajar Bermuatan Nilai-Nilai Karakter Pada Materi Usaha dan Momentum untuk Pembelajaran Fisika Siswa Kelas XI SMA. 1, 63-70.

Anugraheni, I. (2018). Meta Analisis Model Pembelajaran Problem Based Learning dalam Meningkatkan Keterampilan Berpikir Kritis di Sekolah Dasar. 1(1), 9-18.

Arimadona, S., \& Silvina, R. (2019). Pengembangan Modul Pembelajaran Zat Adiktif dan Psikotropika Berbasis Scientific Approach dengan Crossword Puzzle. 3(1), 62-75.

Astari, J. I. R. (2018). Pengoptimalisasi Pendidikan Karakter dalam Pembelajaran Kimia yang Efektif dan Efisien dengan Media Interaktif. J-PEK (Jurnal Pembelajaran Kimia), 3(1), 24-30.

Astuti, D. R., Saputro, S., \& Mulyani, S. (2016). Pengembangan Modul Kimia Berbasis Scientific Approach Pada Materi Ikatan Kimia Kelas X SMA/MA Semester 1. 5(2).

Bhabiet, L., Accraf, R., Khery, Y., Kimia, P. P., Mataram, I., \& No, J. P. (2018). Pengembangan EModul Interaktif Berbasis Android dan Nature Of Science pada Materi Ikatan Kimia dan Gaya Antar Molekul untuk Menumbuhkan Literasi Sains Siswa. Hydrogen: Jurnal Kependidikan Kimia, 6(2).

Budiningsih, C. A. (2015). Karakteristik Siswa sebagai Pijakan dalam Penelitian dan Metode Pembelajaran. Jurnal Cakrawala Pendidikan, 1(1), 160-173.

Darma, E., Putra, S., Maulina, J., \& Pohan, L. A. (2018). Penerapan Model Pembelajaran Problem Based Learning Menggunakan Handout dan Modul Pada Materi Stoikiometri Larutan Di SMA Nurul Amaliyah Deli serdang. 2(1), 1-13.

Dumitrescu, C., Olteanu, R. L., Gorghiu, L. M., \& Gorghiu, G. (2015). Learning Chemistry in the Frame of Integrated Science Modules - Romanian Student's Perception. Procedia - Social and Behavioral Sciences, 116, 2516-2520.

Dwikristanto, Y. P., \& Listiani, T. (2018). Pengembangan Modul Pembelajaran Pengolah Lembar Kerja Excel Berbasis Multimedia. Polyglot: Jurnal Ilmiah, 14(1), 79.

Eliza, F. (2020). Pengembangan Modul Pembelajaran Dasar Listrik dan Elektronika Untuk Kelas X TITL SMK Negeri 1 Padang. 06(02), 227-231.

Erba, O. (2020). Reducing the Effect of Handout Dependent Student Learning on Instructional Time : The Case of Third Year Biology Students at Haramaya University. 5(1), 1-18.

Fatma, Holiwarni, B., \& Susilawati. (2016). The Development of a Comprehensive Intelligence Handout Charged for the Reaction Rate Material on the Grade XI High School. Jurnal Online Mahasiswa Fakultas Keguruan Dan Ilmu Pendidikan Universitas Riau, 1(1), 1-11.

Habibati, H., Nazar, M., \& Septiani, P. D. (2019). Pengembangan Handout Berbasis Literas Sains pada Materi Larutan Elektrolit dan Nonelektrolit. Jurnal IPA \& Pembelajaran IPA, 3(1), 4348.

Haji, A. G., Safriana, \& Safitri, R. (2015). The use of problem based learning to increase students' learning independent and to investigate students' concept understanding on rotational dynamic at students of SMA Negeri 4 Banda Aceh. Jurnal Pendidikan IPA Indonesia, 4(1), 67-72.

Haristah, H., Azka, A., Setyawati, R. D., \& Albab, I. U. (2019). Pengembangan Modul Pembelajaran. 1(5), 224-236.

Haritsah Ulya, Ratu Betta Rudibyani, T. E. (2019). Pengembangan Modul Kimia Berbasis Problem Solving Pada Materi Asam Basa Arrhenius. Jurnal Pendidikan Dan Pembelajaran Kimia, 7(1), 
$129-141$.

Herwati. (2016). Pengembangan Modul Keanekaragaman Aves sebagai Sumber Belajar Biologi. 1(1), 28-36.

Irawati, R. K. (2014). Pengaruh Model Problem Solving dan Problem Posing serta Kemampuan Awal terhadap Hasil Belajar Siswa. 2(4), 184-192.

Irfandi, I., Linda, R., \& Erviyenni, E. (2018). Pengembangan Modul Pembelajaran Kimia Berbasis Learning Cycle - 5E pada Materi Ikatan Kimia. EduChemia (Jurnal Kimia Dan Pendidikan), $3(2), 184$.

Iza, N. kartika S. \& N. (2018). Pengembangan Handout Evolusi Berbasis Hasil Penelitian Profil DNA Fingerprinting. 3(2), 37-47.

Korniawati, A., Kusumo, E., \& Susilaningsih, E. (2016). Validitas Chemistry Handout Sebagai Inovasi Bahan Ajar Stoikiometri Berstrategi PBS Bervisi SETS. Jurnal Inovasi Pendidikan Kimia, 10(1), 1629-1640.

Langitasari, I. (2016). Analisis Kemampuan Awal Multi Level Representasi Mahasiswa Tingkat I pada Konsep Reaksi Redoks. 1(1), 14-24.

Liniswanti, S. (2015). Pembuatan Bahan Ajar Bermuatan Kecerdasan Komprehensif Materi Kalor dan Alat Optik untuk Pembelajaran Siswa Kelas X SMA. 6, 17-24.

Mawarni, E. (2015). Penerapan Peer Tutoring Dilengkapi Animasi Macromedia Flash dan Handout untuk Meningkatkan Motivasi Berprestasi dan Prestasi Belajar Siswa Kelas XI IPA 4 SMAN 6 Surakarta Tahun Pelajaran 2013/2014 Pada Materi Kelarutan dan Hasil Kali Kelarutan. Jurnal Pendidikan Kimia (JPK), Universitas Sebelas Maret, 4(1), 29-37.

Meerah, S. T. (2019). Pengembangan Modul Pembelajaran Mandiri Berbasiskan. 18(2), $127-132$.

Muliawati, D. I., \& Saputro, S. (2016). Pengembangan Handout Berbasis Team Assisted Individualization (TAI) untuk Meningkatkan Prestasi Belajar Siswa Pada Materi Pembuatan Etanol Skala Laboratorium SMK Kimia Industri. 5(1), 37-44.

Muriati, S. (2014). Pengembangan Bahan Ajar Biologi Sel Pada Program Studi Pendidikan Biologi UIN Alauddin Makassar. 1(2).

Nazar, M. (2018). Pengembangan Hand-Out Konsep Larutan Berintegrasi Nilai Religi untuk Meningkatkan Minat Belajar Siswa SMA pada Pondok Pesantren Terpadu. 06(02), 95-100.

Noorhidawati, A., \& Gibb, F. (2008). How students use e-books - reading or referring? Malaysian Journal of Library and Information Science, 13(2), 1-14.

Novitasari, E., Masykuri, M., \& Aminah, N. S. (2016). Pengembangan Modul Pembelajaran IPA Terpadu Berbasis Inkuiri Terbimbing Tema Matahari Sebagai Sumber Energi Alternatif di Kelas VII SMP/MTs. 5(1).

Nugroho, Y. S., Achmad, F., \& Rohman, M. (2019). Pengembangan Modul Pembelajaran Mata Kuliah Energi Alternatif Program Studi Pendidikan Vokasinal Teknik Elektro. 5(1), 93-106.

Nursafitri, L., Widaryanto, W., \& Zubaidi, A. (2020). Pengembangan Modul Pembelajaran Pendidikan Agama Islam ( PAI ) Kelas IV Madrasah Ibtidaiyah. 4(1), 91-99.

Parsudi, Y., Lukman, A., \& Kartika, W. D. (2017). Pengembangan Handout Pembelajaran Biologi Tentang Restorasi Ekosistem Mangrove Berbasis Socioscientific Issues di SMA. Jurnal Pendidikan Biologi FKIP Universitas Jambi, http://repository.unja.ac.id/1771/1/RSA1C412019-ARTIKEL.pdf

Plangsorn, B. (2017). Development of Producing and Using E-books Competencies of Teachers in Chachengsao, Thailand. 9(2), 112-117.

Prastyaningrum, I., \& Imansari, N. (2016). Pengembangan Modul Pembelajaran Mata Kuliah Teori Medan. 1(2), 56-61.

Pratama, D. P. A., \& Sakti, N. C. (2020). Pengembangan Media Pembelajaran Handout Digital Berbasis Android Pada Materi APBN dan APBD Kelas XI IPS. Jurnal Pendidikan Ekonomi Undiksha, 1(1), 43-53.

Pujiastuti, D. (2018). Pengembangan Handout Kimia Berbasis Inkuiri Terbimbing Dilengkapi Media Grafis Pada Materi Ikatan Kimia MA. Seminar Nasional Pendidikan Fisika, 3, 305-311.

Purwo, W. (2016). Makalah Pendamping Peran Pendidik dan Ilmuwan dalam Menghadapi MEA ISSN: 2527-6670 Pengembangan Modul Fisika Berbasis Generative Learning Untuk Meningkatkan Kemampuan Berpikir Kritis Siswa. 66-71.

Rahmayani, F., Hindun, I., \& Miftachul Hudha, A. (2015). Pengembangan Handout Berbasis 
Kontekstual pada Pelajaran Biologi Materi Bioteknologi untuk Siswa Kelas XII SMK Negeri 02 Batu. Jurnal Pendidikan Biologi Indonesia, 1(1), 47-59.

Rinaningsih. (2014). Implementasi Model Perkuliahan Terpadu Sorogan-Bandongan untuk Menentukan Pemahaman Mahasiswa dalam Mempelajari Mekanisme Reaksi. 19(2), 266-274.

Rofiah, E., Aminah, N. S., \& Sunarno, W. (2018). Pengembangan Modul Pembelajaran IPA Berbasis High Order Thinking Skill (HOTS) untuk Meningkatkan Kemampuan Berpikir Kritis Siswa Kelas VIII SMP/MTs. INKUIRI: Jurnal Pendidikan IPA, 7(2), 285-296.

Rokhimah, S., Fatmaryanti, S. D., \& Nurhidayati, N. (2018). Pengembangan Handout Logan Avenue Problem Solving (LAPS-Heuristik) Bermuatan Multi Representasi untuk Meningkatkan Kemampuan Bahasa Simbolik Peserta Didik Kelas XI. Radiasi : Jurnal Berkala Pendidikan Fisika, 11(2), 59-65.

Salfrika, A. T. (2016). Pengembangan Handout Berbasis Kontekstual pada Materi Faktor- faktor yang Mempengaruhi Laju Reaksi untuk SMA / MA Kelas XI IPA. Jurnal Ilmiah Mahasiswa Pendidikan Kimia (JIMPK), I(3), 17-26. http://jim.unsyiah.ac.id/pendidikankimia/article/view/1296

Saraswaty, S., Masykuri, M., \& Mulyani, S. (2019). Pengembangan Modul Berbasis Inkuiri Terbimbing pada Materi Kimia Larutan Penyangga untuk Meningkatkan Keterampilan Berpikir Kritis Siswa Kelas XI SMA di Karanganyar. INKUIRI: Jurnal Pendidikan IPA, 8(2), 110-118.

Sari, S. A., . J., Kembaren, A., \& Sudrajat, A. (2018). The Development of Handout Based on Guided Note Taking To ImproveThe Quality of Analytical Chemistry Learning. PEOPLE: International Journal of Social Sciences, 4(3), 720-734.

Septryanesti, N. (2019). Desain dan Uji Coba E-Modul Pembelajaran Kimia Berbasis Blog Pada Materi Hidrokarbon. 2(4), 202-215.

Silfi, A., Syakbaniah, Y., \& Kamus, Z. (2014). Pengembangan Handout Berbasis Model Sains Teknologi Masyarakat Pada Materi Wujud Zat Dan Perubahan Zat Untuk Pembelajaran IPA Fisika SMP Kelas VII SEmester 1. 3,9-16.

Sistyarini, D. I., \& Nurtjahyani, S. D. (2017). Analisis Validitas terhadap Pengembangan Handout Berbasis Masalah pada Materi Pencemaran Lingkungan Kelas VII SMP / MTS Analysis of The Validity of the Development of Problem Based Handout on Environmental Content Chapters Class VII SMP / MTS. Proceeding Biology Education Conference, 14(2014), 581-584.

Siti, D., Audina, M., Kosasih, E., \& Respati, R. (2018). Pengembangan Bahan Ajar (Handout) Ritmis untuk Siswa Kelas I Sekolah Dasar. PEDADIDAKTIKA: Jurnal Ilmiah Pendidikan Guru Sekolah Dasar, 5(3), 276-286.

Situmorang, M. (2013). Pengembangan Buku Ajar Kimia Sma Melalui Inovasi Pembelajaran Dan Integrasi Pendidikan Karakter Untuk Meningkatkan Hasil Belajar Siswa. 237-246.

Sumiati, S., Arcana, I. N., \& Taufiq, I. (2019). Modul Geometri Kubus dan Balok pada Pembelajaran Think Pair Share Berbasis Ajaran Ki Hadjar Dewantara. UNION: Jurnal Ilmiah Pendidikan Matematika, 7(3), 329.

Suparmi, et al. (2019). The Use of Inquiry-Based Handouts on Science Learning for Student Critical Thinking Ability. 3(3), 353-363.

Wahidin, U. (2018). Implementasi Literasi Media dalam Proses Pembelajaran Pendidikan Agama Islam dan Budi Pekerti. 7(2), 229-244.

Wang, X. (2018). Using E-Books to Motivate Children's Learning Of English As A Second Language.

Wati, Li. (2017). Desain Bahan Ajar Berupa Handout Berbasis Inkuiri Terbimbing Pada Pembelajaran Kimia Materi Hidrokarbon. 1(2), 219-224.

Wisnu, I. K., Wijaya, B., Fajar, A. M., Tukad, J., Ix, B., \& Selatan, D. (2020). Pengembangan Modul Pembelajaran Berorientasikan Problem Based Learning (PBL) untuk Meningkatkan Keterampilan Proses Sains Siswa Pada Materi Cahaya dan Alat Optik. 11(1), 8-17.

Zohrani, E. (2018). Pengembangan Bahan Ajar Laju Reaksi Dengan Modelinquiry Berbasis Android Untuk Menumbuhkan Literasi Sains Siswa. September, 169-186.

Zuhri, W. (2014). Pengembangan E-Modul Berbasis Flip Book Maker dengan Model Project Based Learning untuk Mengembangkan Kemampuan Pemecahan Masalah Matematika. Prosiding Mathematics and Sciences Forum, 625-628. 